\title{
Governance the Utilization of Protected Forest of Sungai Wain (HLSW) With a Pattern of Incentives and Disincentives in Balikpapan City
}

\author{
Soetoyo, Maryunani, Soemarno, Olly Esry H. Laoh \\ (Faculty of Agriculture, Brawijaya University, Indonesia)
}

\begin{abstract}
The mechanism of incentive and disincentive given in formal organizations such as farmers, namely: Gapoktan, Forum of forest Farmers and farmers groups supporting forest governance of HLSW sustainable. The research explained that mechanism incentive and a disincentive to organizations formal farmers in group incentives indirectly, with category sector incentives and enabling incentives. The type of incentive that is measured by the variable response and socio-economic conditions of the Community farmer explained that the type of incentives issued by the holder of the regulation in the utilization of protected forest governance Sungai Wain (HLSW) fall into the category of quadrants I and IV. Quadrant I) explained that an incentive-based community empowerment is required by the farming community forests in protected forest Sungai Wain (HLSW) to preserve its sustainable conservation. (Quadrant IV) describes the response of the Community farmer's low against these types of incentives issued by the holders of protected forest management regulations Sungai Wain $(H L S W)$. The type of incentive is so normative and not in accordance with standard quality of goods that are expected by farmers. (Quadrant IV) describes the response of the Community farmer's low against these types of incentives issued by the holder of the regulation of the management of Sungai Wain (HLSW). The type of incentive is so normative and not in accordance with standard quality of goods that are expected by farmers.

Behavior villagers forest governance associated with HLSW categorized in support and maintain the conservation forest participate in the sustainable and sustainability. Behavior of villagers described three aspects, with forest social aspect, namely: economic aspect cultural aspect. Mapping the distribution of stakeholders based on the strengths and interests of the stakeholder group which produces: (1) great power and great interests consist of: UP HLSW, BLH, BP DAS Mahakam Berau, (2) the power of a small but substantial interests consist of: the community forest village, DTKP and Balikpapan Pertamina UP V, (3) the power of a small but small interests consist of: PT. Singlurus Pratama, and (4) Great power but small interests consist of: DISPORABUDPAR, DISDIK, BPMPPKB and DINKES.

Factors supporting the socio economical that is being base main in formulating policies supporting the pattern incentives in governance HLSW with scored 0,788. Score who gets ranking I (first) showed factor supporting believed by group villagers forest area in HLSW and the parties related with governance HLSW sustainable and sustainability. Factor supporting social capital scored 0,165 while factor supporting socio ecological scored 0,182 .
\end{abstract}

Keywords: Governance, Incentive-Disincentive Systems and Paradigm of Sustainable Forest.

\section{Introduction}

Development forestry sustainable everlastingly involve all stakeholders in the process of decision making. Empirically prove about the contribution forestry for food safety, energy, nutrition and human security. Behavior villagers forest relating to governance hlsw included in the category support and to partake in maintain the preserved forest sustainable and sustainability. Behavior of villagers forest explained by three aspects, namely: social aspect, aspect economic aspect culture. This was confirmed by Padoch (2012), individually or in group shows that the linkages between forests and food security are multidimensional, complex and often difficult to observe, didokumentasi and measured. The key to understanding it is to appreciate the diversity of shapes and dimensions.

In the context of indonesia the aspect of coordination also cannot be released in the implementation of governance hutan.transparansi, participation, accountability and coordination seen not as something new. But until now, the most appropriate form to translate aspects of good governance (good governance) for forestry in Indonesia have not been agreed upon. Indonesian Climate Change Sectoral Roadmap/ICCSR, (2009) report that the factors causing deforestation Indonesia is due to fundamental issues, among others, are: (1) the conversion of natural forests into annual crops, (2) the conversion of natural forests into agricultural land, (3) extractive industries exploration on forest areas (coal, oil and gas, geothermal), (4) burning of forest and land, and (5) conversion for resettlement and other infrastructure. In addition to the five factors mentioned above, in some areas of the forest damage thus caused by the expansion of new autonomous region. 
Besides factor that has been mentioned by ICCR, the destruction of forests is now Indonesia is due to various things such as illegal logging (illegal logging), forest fires, encroachment, and others. The root of the problem is yet to materialize good forest governance (good forest governance). Good governance forest would be to improved various aspects that supports it as engineering, management of forest forestry integrity, human resources (intellectuality, moral), the legislative and security devices and surveillance. Some kajian governance yield conclusions: among other legislation concerning forestry in indonesia inclined simpangsiur and overlapping ( Moeliono and Djogo, in 2001, Ginoga, et al., 2005); there are perceptual difference between the central government and regional government regarding forest management everlastingly prompting ketidaksinkronan and inconsistencies between the central and regional regulation (Elvida and Sukadri, 2002; Ginoga, et al., 2005 ).

Sustainable forest management can not be removed with the existence of the farming community forests in protected forest area of the river Waijn (HLSW). Forest village community as local people will always be in the flow of social cultural, economic, ecological and demographic. (Chomitz et al. 2007; Lynch and Talbott 2001; Suharjito at al. 2000). This is due to that masyarakt forest villages as local communities have an adaptive system in forest management (Edmuns and Wollenberg 2003; Nath 2005; Claridge and O'Callaghan 1995; Korten 1986) as institutional traditions (Golar 2007; Wiratno et al 2004) and social capital (Suharjito and Saputro 2008).

The phenomenon of the protection and management of protected forest to include the role of the parties and the public also occur in protected forest Sungai Wain (HLSW) in sub-district Balikpapan North. On the concept of desire that the interaction between the protected forest and community living were constructed, so that the maximum benefit without omitting preserved. Protected forest of Sungai Wain (HLSW) is the only protected forest in Balikpapan of East Kalimantan Province. Local government (local government) issued a regulation to protect the Balikpapan HLSW of human economic activity that threatens preserved.

One of the regulations issued by the local government Balikpapan protected forest sustainability in looking after The wine (HLSW) is to provide incentives and disincentives on mechanical farmers group forest and protected forest area. This is as described by Pasya (2002), which suggests the importance of the development of the mechanism of incentives and disincentives in policy management of natural resources in the Forest Ecosystem. The mechanism of incentive and disincentive is the thesis early to suppress the effects of activities in the social, economic and cultural centre of village community forests to the existence of protected forest so that the existence of the protected forest maintained preserved in the long run.

\section{Research Methods}

This research was carried out in the area of protected forest River wine (HLSW) in Balikpapan of East. The location of the research carried out on the basis of a scientific judgment that the Region protected forest River wine (HLSW) has a competitive advantage from the aspect of socio-ecological. The biodiversity of the Protected forest area Sungai Wain (BPHLSW) also be determining factors pemelihan location research. The data analysis used in the study, namely: analysis of incentives and Disincentives (Sanders and Cahlil 1999); Interpretive paradigm (Lexy J Moloeng, 2004); Stakeholder analysis is the PILL ( $\mathrm{P}=$ Power, I = Interest and L = legitimate), Grimble and Wellard (1997) and Hirarchi Process Analysis/AHP (Thomas 1. Saaty, 2008).

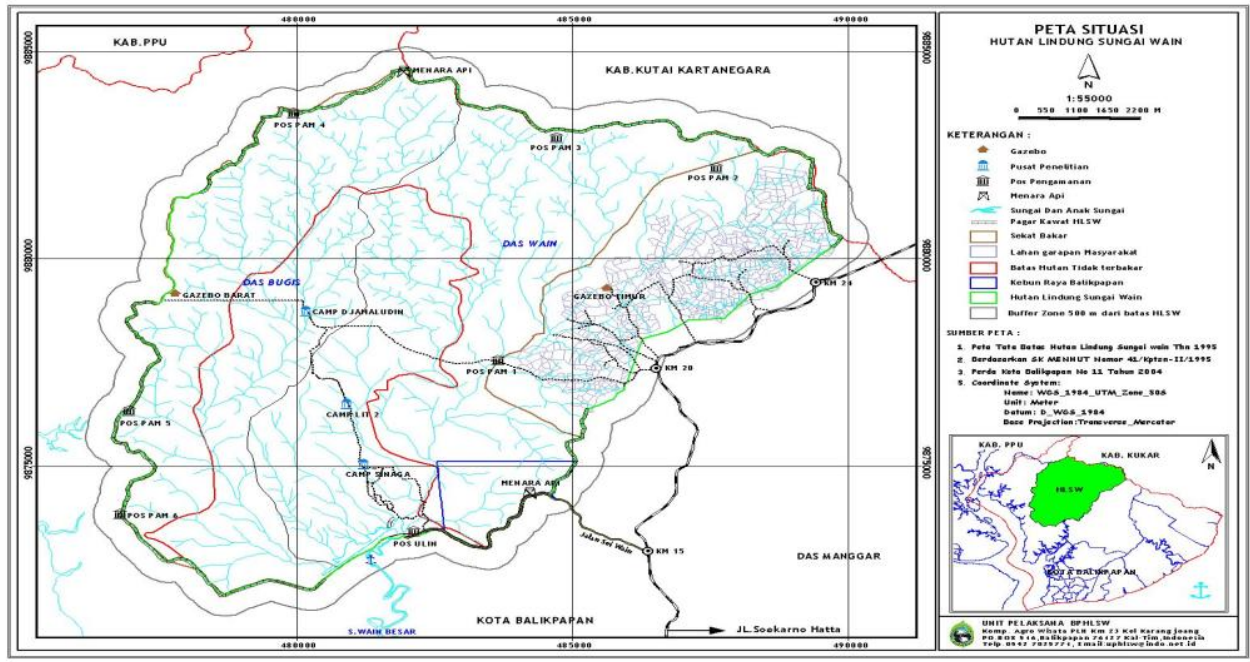

Fig.1. Research Location Map 


\section{Empirical Result}

Farmers group in the perspective of forest governance HLSW is a collection of forest farmers who have the right to manage the lowliest HSLW especially in Judg. management model the role of farmer groups, according to Abbas (1995), has great potential in its role as: (1). Classroom teaching and learning means the farmers group is a container for each Member of the group to interact in order to increase the knowledge, skills and attitudes in better farming and profitable as well as foster a drive for more independent, (2). The cooperation means that the farmers group is a container for the strengthening of cooperation between farmers within the Group and between groups with others to confront various threats, challenges, barriers, and the failure of pre harvest, post-harvest, marketing and capital so that farmers have a fertilizing power of bargaining (bargaining position).

On the corporate governance of the utilization of protected forest River Wine at Balikpapan in addition is determined by the existence of a formal organization of farmers. (as of empirical facts above) then it needs any incentive and disincentive mechanisms needed to support the position, role and function of the formal organization of farmers. To find out the factors that are incentive and disincentive to the HLSW governance will be done with the analysis of incentive. This analysis aims to find out whether the formal organization of farmers already in accordance with the wishes and needs of farmers. Conformity with the conditions and needs of farmers is vital as capital for farmers to participate in the governance of an enduring and sustainable HLSW.

Analysis of the results obtained through in-depth interviews with experts (the interview was conducted to determine the factors that influence the incentives and disincentives). Results of the in-depth interviews are then classified and formed a table on the basis of answers parties, analysis of data done in a descriptive. Analysis incentives using typology incentives according to enters (1999).

Table 1: Description of the Mechanism of Incentives and Disincentives on Farmer's Organization in the HLSW Sustainable Governance and Sustainability

\begin{tabular}{|c|c|c|c|}
\hline Organization Type & Incentives & Disincentives & Description \\
\hline $\begin{array}{l}\text { Combination of } \\
\text { Farmer Groups } \\
\text { (Gapoktan) }\end{array}$ & $\begin{array}{l}\text { - Means of production, } \\
\text { - Seedlings, } \\
\text { - Drugs, } \\
\text { - Fertilizer, } \\
\text { - Capital, } \\
\text { - Extension }\end{array}$ & $\begin{array}{l}\text { - Fines, } \\
\text { - Temporary suspension of } \\
\text { business/activity, } \\
\text { - Revocation of license. }\end{array}$ & $\begin{array}{l}\text { - Decree Minister of Agriculture } \\
\text { Number } 24 / \text { Kpts/UM/I/1983, } \\
\text { - Decree Minister of Forestry Number } \\
\text { 118/Kpts-VII/1998, } \\
\text { - Regulation of the Balikpapan City } \\
\text { Number } 11 \text { of } 2004\end{array}$ \\
\hline $\begin{array}{l}\text { Forums } \quad \text { Forest } \\
\text { Farmer }\end{array}$ & $\begin{array}{l}\text { - Means of Production, } \\
\text { - Seedlings }\end{array}$ & $\begin{array}{l}\text { - Land acquisition of the } \\
\text { building remains with a } \\
\text { distance of } 200 \mathrm{~m} \text { from the } \\
\text { road }\end{array}$ & $\begin{array}{l}\text { As suggested by the community } \\
\text { released } \pm 500 \mathrm{M} \text { from the edge of } \\
\text { the highway Balikpapan - Samarinda } \\
\text { between km. } 20-24 \text {, by the Decree } \\
\text { Minister of Forestry No: } 416 / \mathrm{Kpts}- \\
\text { II/1995 dated August } 10,1995\end{array}$ \\
\hline $\begin{array}{r}\text { Forest } \\
\text { Farmer Groups }\end{array}$ & $\begin{array}{l}\text { - Seeds of annual plants, } \\
\text { - Certification rights of } \\
\text { land management }\end{array}$ & $\begin{array}{l}\text { - Revocation Rights Manage } \\
\text { forest community for } 15 \text { years } \\
\text { if it fails to manage, } \\
\text { - The transfer of processing to a } \\
\text { group of farmers when the } 3 \text { - } \\
\text { year period is not utilized. }\end{array}$ & $\begin{array}{l}\text { Regulation of the Minister of Forestry } \\
\text { No P.37/Minister of Forestry-II/2007 }\end{array}$ \\
\hline
\end{tabular}

Source: The Survey Results, January 2013

The table above describes the mechanism of incentive and disincentive conducted as an instrument to regulate the governance of utilization of protected forest of Sungai Wain (HSLW) in the long-term in order to remain sustainable and sustainability. Types of incentives and disincentives in the table above when analyzed with analysis of the Incentive of Sanders and Cahlil (1990) entered in the Group Incentive Not Directly with categories of Sector Incentives and Enabling Incentives. Results of analysis between the type of incentive factually and theoretically Cahlil of Sanders (1990) can be seen in the table below.

Table 2: The Result Analysis between Incentive and Disincentive Factually with Theoretical in Governance HLSW Sustainable and Sustainability 


\begin{tabular}{|c|c|c|c|c|}
\hline \multirow[b]{2}{*}{ No } & \multicolumn{2}{|r|}{ Factual } & \multicolumn{2}{|r|}{ Theoretical } \\
\hline & Incentive & Disincentive & Sector Incentives & Enabling Incentives \\
\hline 1 & $\begin{array}{l}\text { - Means of production, } \\
\text { - Seedlings, } \\
\text { - Drugs, } \\
\text { - Fertilizer, } \\
\text { - Capital, } \\
\text { - Extension } \\
\end{array}$ & $\begin{array}{l}\text { - Fines, } \\
\text { - Temporary suspension of } \\
\text { business/activity, } \\
\text { - Revocation of license. }\end{array}$ & $\begin{array}{l}\text { - incentives variable } \\
\text { input, } \\
\text { - Incentives variable } \\
\text { external/output } \\
\text { - Subsidies }\end{array}$ & - Market Development \\
\hline 2 & $\begin{array}{l}\text { - Means of Production, } \\
\text { - Seedlings }\end{array}$ & $\begin{array}{l}\text { - Land acquisition of the } \\
\text { building remains with a } \\
\text { distance of } 200 \mathrm{~m} \text { from the } \\
\text { road }\end{array}$ & & - Security of land \\
\hline 3 & $\begin{array}{l}\text { - Seeds of annual plants, } \\
\text { - Certification rights of } \\
\text { land management }\end{array}$ & $\begin{array}{l}\text { - Revocation Rights Manage } \\
\text { forest community for } 15 \text { years } \\
\text { if it fails to manage, } \\
\text { - The transfer of processing to a } \\
\text { group of farmers when the } 3 \text { - } \\
\text { year period is not utilized. }\end{array}$ & & $\begin{array}{l}\text { - Security of land, } \\
\text { - Devolution of natural } \\
\text { resource management }\end{array}$ \\
\hline
\end{tabular}

Source: The Survey Results, January 2013

A table on to explain that theoretically, the mechanism of incentives and a disincentive in governance utilization protected forest of Sungai Wain (HLSW) entered into two categories kinds of incentives that is kind of sector incentives and enabling incentives Of the above types of incentives then performed an analysis of the level of incentives. The incentives levels based on its impact to the farmers. The impact on society of farmers to incentives is measured based on two variables, namely the response from the farming community and the condition of the farmers. The response of the Community farmer of incentives that have been issued by officials would fall into the category of high or low. Besides against response of farmer community also what deserves consideration is how conditions socially economy, farmer community are included in the category of high society economically or socially in the classification of farmer community with social

Table 3: Results of Rating Type Incentives in Sustainable HLSW Governance and Sustainability

\begin{tabular}{|c|c|c|c|}
\hline \multirow[t]{2}{*}{ Incentive Type } & \multicolumn{2}{|c|}{ Community Response } & \multirow{2}{*}{ Description } \\
\hline & High & Low & \\
\hline $\begin{array}{l}\text { Means of } \\
\text { production }\end{array}$ & & v & $\begin{array}{l}\text { Incentive means of production for farmers group gets low response. Means of } \\
\text { production that they receive is only used in the production of abundant, especially of } \\
\text { the type of production processing products. }\end{array}$ \\
\hline Seedlings & & v & $\begin{array}{l}\text { Incentives in the form of crop seeds received a low response from farmers' groups. } \\
\text { This was due to the poor quality of seeds given that affects the quality of plants and } \\
\text { products. }\end{array}$ \\
\hline Drugs & & v & $\begin{array}{l}\text { Incentives in the form of drugs received a low response from farmers' groups. This } \\
\text { was due in the long run will damage the fertility of the land. Therefore farmer } \\
\text { groups did not rely entirely on the use of drugs in the treatment of their crops. }\end{array}$ \\
\hline Fertilizer & & v & $\begin{array}{l}\text { Incentive in the form of fertilizer gets low response from farmers' groups. This is } \\
\text { because more farmers use manure obtained from breeders group. They think } \\
\text { fertilizer is too expensive and difficult to reach by their price. }\end{array}$ \\
\hline Capital & $\mathrm{v}$ & & $\begin{array}{l}\text { Incentive in the form of capital gets high response from the farmers group. This is } \\
\text { because each planting season beginning farmers the trouble of capital. }\end{array}$ \\
\hline Extension & & v & $\begin{array}{l}\text { Incentives in the form of field extension workers received low response from } \\
\text { farmers' groups. It is because farmers assume exertion counselors roomy only } \\
\text { mastered theoretically course. Issues directly related to the technical production of } \\
\text { farmers based on the experience gained. }\end{array}$ \\
\hline $\begin{array}{l}\text { Seeds of annual } \\
\text { plants }\end{array}$ & $\mathrm{v}$ & & $\begin{array}{l}\text { Incentives in the form of crop seeds received a high response of forest farmer } \\
\text { groups and farmer forums forests. The farmer groups were in the community forest } \\
\text { area and buffer zone or non Community Forest. High rate of response was due to the } \\
\text { group depends on the ability of the farmer to cultivate land by the number of seeds it } \\
\text { has. Land that can be processed if no seeds are planted also affects their income. } \\
\text { Therefore incentives are expected annual plant seeds by farmers }\end{array}$ \\
\hline $\begin{array}{l}\text { Cert } \\
\text { ification } \\
\text { of rights } \\
\text { management }\end{array}$ & $\mathrm{v}$ & & $\begin{array}{l}\text { Incentives in the form of land use rights certificates gets steeper response of forest } \\
\text { farmer groups in the area of community forestry. This was due to the guarantee of } \\
\text { the certainty of the results of their work to cultivate land owned by the State. } \\
\text { Certification of forest management rights for farmers to make peace of heart and } \\
\text { mind to cultivate the land in the long term. For farmers forest management } \\
\text { certification of land rights is de facto proof of land ownership for } 20 \text { years. Even } \\
\text { after } 20 \text { years will be evaluated against the results of the management of the land. }\end{array}$ \\
\hline
\end{tabular}

Source: The Survey Results, January 2013

The above table describes the results of an analysis of the types of incentives are measured based on the response of the farming community. Types of incentives based on farmer's responses were then analyzed by 
socio-economic conditions of the farmers. Analysis of the types of incentives that the results measured by response variable socio-economic conditions of farmers and farmers can be seen in the diagram below.

Diagram 1: Results of Analysis of the Response Incentive Type and Socio-Economic Conditions Community Farmers

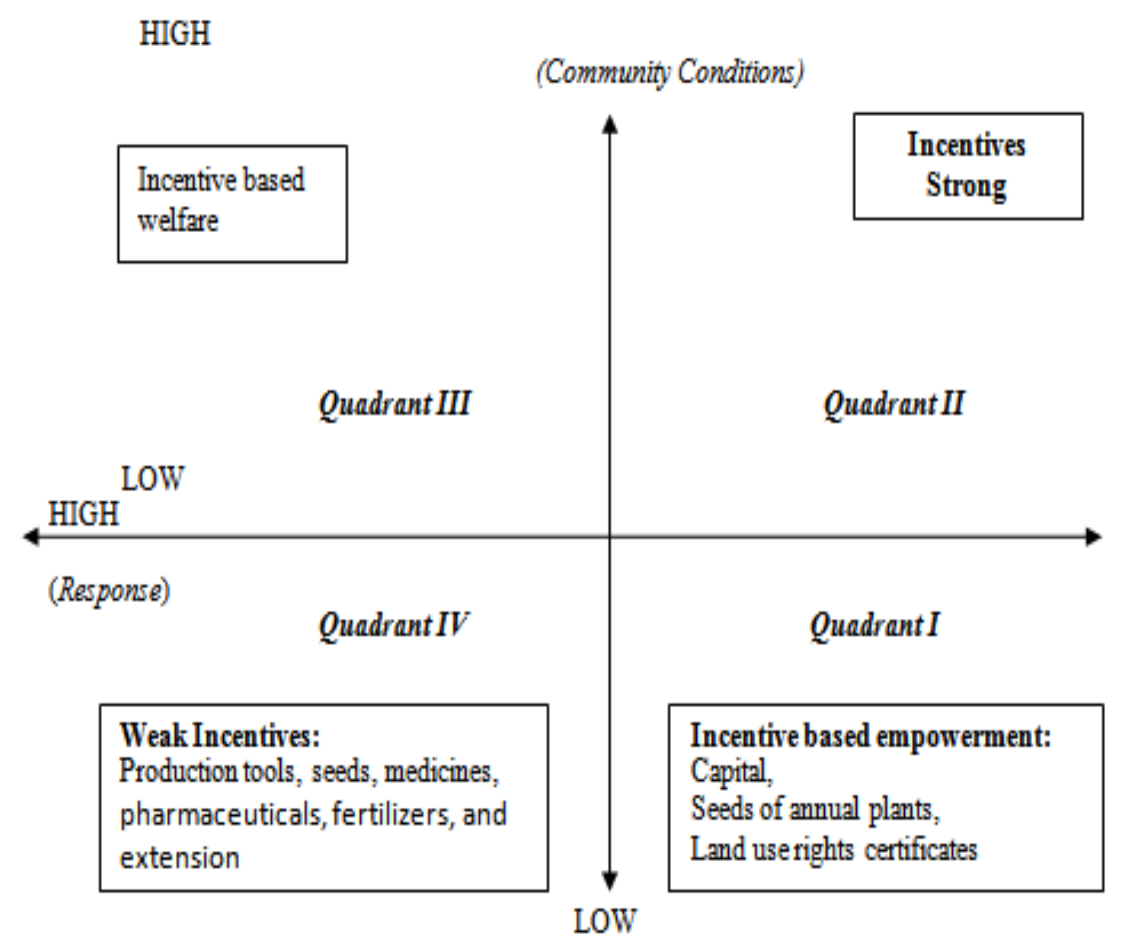

Analysis of the types of incentives that the results measured by the response variable and the socioeconomic conditions of the farmers explained that this type of incentive regulation issued by the holder governance utilization the Protection Forest of Sungai Wain (HSLW) in the category of Quadrant I and IV. Quadrant I explained that incentive-based community empowerment is needed by farmers in the forest areas of Sungai Wain Protection Forest (HSLW) in order to secure sustainable conservation. This can be explained by the high response peasant society on the type of incentive. (See table 5.4). Quadrant I also explain the substance of the farming community forest low socioeconomic category that requires the kind of incentives that can significantly improve their welfare in the long run. Three farmer groups in the area of Protection Forest Sungai Wain (HSLW) is Gapoktan, Farmers Forum Forests and Forest Farmers Group as a whole requires the kind of incentives that are described in the diagram above. Gapoktan focus more on incentives types of capital, while the forum is forest farmers needed seed capital and annual plants. Forest

Quadrant IV explains the low response of the farmers to the type of incentive regulation issued by the holder of the management Protection Forest of Sungai Wain (HLSW). Types of incentives are very normative and not according to the standard quality of goods that are expected by the farmers. In addition to the result of the perceived not affect significantly if receive the incentives. Although the socio-economic condition of the farmers in the low category they do not expect in depth to obtain the types of incentives. In addition to not affect production, farming communities have local knowledge in lieu of the types of incentives. It is given or not is kind of incentive does not affect the welfare of economically and environmentally in the HLSW.

Pattern of the system of incentives and disincentives in the Sungai Wain Protection Forest area (HSLW) which is based on regulation if the above analysis is based on the characteristics of the policy can provide the enabling or inhibiting effect. Results of an analysis of the patterns of incentives and disincentives in the region Sungai Wain Protection Forest (HLSW) can be seen in the table below.

Table 4: Results on Pattern Analysis Incentives and Disincentives in Sungai Wain Protection Forest (HLSW)

\begin{tabular}{|l|l|l|l|l|}
\hline \multirow{2}{*}{ No } & Policy & \multicolumn{2}{|c|}{ Characteristics } & \multirow{2}{*}{ Description } \\
\cline { 3 - 4 } & & Support & Inhibitory & \\
\hline
\end{tabular}




\begin{tabular}{|c|c|c|c|c|}
\hline 1 & Policy Status & V & & $\begin{array}{l}\text { Incentive and disincentive policies provide the conditions } \\
\text { that the HLSW awake preserved in the long run because } \\
\text { of the ever-increasing activities to undermine the good in } \\
\text { quantity as well as quality. }\end{array}$ \\
\hline 2 & $\begin{array}{l}\text { Distribution } \\
\text { Problems }\end{array}$ & & $\vee$ & $\begin{array}{l}\text { Issues in the governance of the utilization of HLSW } \\
\text { enough variety, not only on the technical aspects of } \\
\text { management but also regarding non technical aspects of } \\
\text { management. Non technical aspects of problems that often } \\
\text { cannot be addressed by implementing so often } \\
\text { overlooked. Non technical issue into a point crucial in } \\
\text { HLSW that governance has not been clearly outlined in } \\
\text { the regulation. }\end{array}$ \\
\hline 3 & Purpose & V & & $\begin{array}{l}\text { The purpose of the granting of incentive and disincentive } \\
\text { so pattern effect on the parties which directly or indirectly } \\
\text { have an interest in the presence of HLSW. }\end{array}$ \\
\hline 4 & $\begin{array}{l}\text { Attitude of Land } \\
\text { Users }\end{array}$ & V & & $\begin{array}{l}\text { The forest farmer located in the HLSW supports and } \\
\text { contributes to maintaining continuity with HLSW that } \\
\text { their live with the family of the HLSW depends entirely. } \\
\text { This realization becomes a capital basis for the realization } \\
\text { of farmers to participate in the governance of an enduring } \\
\text { HLSW and sustainability }\end{array}$ \\
\hline 5 & $\begin{array}{l}\text { Evaluation } \\
\text { Process }\end{array}$ & & V & $\begin{array}{l}\text { The evaluation conducted in the pattern of incentives and } \\
\text { disincentives in the HLSW very slowly so that it affects } \\
\text { the process of enforcement of the rules on the field as a } \\
\text { result of farmers often ignore them when they are in } \\
\text { trouble economically. }\end{array}$ \\
\hline
\end{tabular}

On the management and utilization of the HLSW there are some problems faced especially in the area of community forest and non-forest community. Various constraints faced by the community forest and non forest community divided by two sources, namely from the local government (Management Board) and the community (community forest management group). At the Board level HLSW problems faced by business is the quantity and quality limited personnel resources, lack of means of support to the funding and the vast area of community forest area. While the problems at the level of farmers' groups such as the lack of public forest policy dissemination Community forests by personnel of the business, the process of obtaining permission Community forestry is too long and tiring, overlapping government policy, and control / supervision by the Management Board is not participatory.

\section{Conclusions}

This study aims to explain the governance of the use of Sungai Wain Protection Forest (HLSW) that are sustainable and sustainability. The end result of this research resulted in several conclusions, among which are: The mechanism of incentives and disincentives given to the formal organization of farmers who in this case is Gapoktan, Farmers Forum Forests and Forest User Groups in supporting sustainable governance and sustainability HLSW seen from the aspect of socio-economic fall into two categories of types of incentives are the type of sector incentives and type of enabling incentives. Types of incentives as measured by the response variable and the socio-economic conditions of the farmers explained that this type of incentive regulation issued by the holder of the governance utilization Sunga Wain Protection Forest (HSLW) in the category of Quadrant I and IV.

Quadrant I explained that incentive-based community empowerment is needed by the farming community forest in Sungai Wain Protection Forest (HSLW) in order to secure sustainable conservation. Quadrant IV explains the low response of the farming community against this type of incentive normative and not in accordance with the quality standards expected by the farmers' goods. Besides impact perceived against the result of no effect significantly if receive kind of incentives. System of incentives and disincentives in the area of Sungai Wain Protection Forest (HSLW) which is based on aspects of the regulation describes the status of policies, goals and attitudes of land users have the characteristics to support the governance HLSW sustainable utilization and sustainability, and vice versa on the distribution aspects of the problem as well as the evaluation process has the characteristics to inhibit.

The behavior associated with forest village community governance HLSW belongs to the category supports and participates in maintaining sustainable protected forest conditions and sustainability. The behavior of the community forest village described in three aspects, namely:

a. Social aspects consist of: (1). Clear boundaries between areas of forest villagers with protected forests, (2). Land tenure conflict resolution mechanism is effective, (3). Availability of community organizations in the management of protected areas, (4). Community involvement in the management of protected areas, and (5). Balance of rights and obligations of stakeholders in the use of protected areas, 
b. Economic aspects consist of: (1). Opportunities in employment and business opportunities around natural attractions and cultural/use zones in protected areas, and (2). Use of biodiversity through cultivation, use of biological diversity through cultivation,

c. Cultural aspects consist of local cultural practices in the conservation of protected areas

Factors supporting the socio economical basis of formulate policies that support the implementation of the incentive pattern in HLSW governance with score 0,788. Score that got the rank I (first) shows supporting factors believed by community groups in the forest village of HLSW and the parties related to the governance of sustainable HLSW. Factors supporting social capital got a score of 0,165 while supporting the socio-ecological factors scored 0,182 .

\section{References}

[1]. Chomitz K., Giacomo, DL., Piet B., Timothy ST., Sheila WK., 2007. Perluasan Pertanian, Pengentasan Kemiskinan dan Lingkungan di Hutan Tropis. Laporan Penelitian Kebijakan Bank Dunia. Salemba Empat: Jakarta.

[2]. $\quad$ Edmuns D., Wollenberg E. 2003. Local Forest Management.the Impacts of Devolution Policies. London: Earthscan Publications

[3]. Golar. 2007. Strategi Adaptasi Masyarakat Adat Toro. Kajian Kelembagaan dalam pengelolaan dan pemanfaatan sumberdaya hutan di Taman Nasional Lore Lindu Propinsi Sulawesi Tengah. Bogor:

[4]. Ginoga, K., M. Lugina, D Djaenudin. 2005. Kajian Kebijakan Pengelolaan Hutan Lindung. Jurnal Penelitian Sosial dan Ekonomi Kehutanan. Pusat Penelitian dan Pengembangan Sosial Budaya dan Ekonomi Kehutanan. Bogor.

[5]. Grimble, R. and Wellard, K. 1997. StakeholderMethodologies in Natural Resource Management: A review of concepts, contexts, experiences and opportunities, Agricultural Systems 55: 173-193.

[6]. Indonesia Climate Change Sectoral Roadmap, ICCSR. 2009. Indonesia National Development Planning Synthesis Report

[7]. Lexy J Moloeng, 2004. Metode Penelitian Kualitatif, Remaja Rosda Karya, Bandung, hal 138.

[8]. Ostrom,E., 1990. Governing the Commons : The Evolution of Institutions for Collective Action. New York.Cambridge University Press.

[9]. Padoch, C. 2012. Borneo in Transition: People, Forests, Conservation, and Development, Oxford University Press, Kuala Lumpur

[10]. Pasha, Gamal. 2002. Jasa Lingkungan dan Mekanisme Insentif/Disinsentif Pengelolaan SDA Dalam Ekosistem DAS. Makalah Seminar 'Enviromental Good Governance dalam Kebijakan Pemda yang berkaitan dengan Pengelolaan SDA dan Lingkingan di Era Otonomi Daerah. Bappeda Propinsi Lampung.

[11]. Suharjito D., Saputro E. 2008. Modal Sosial Dalam Pengelolaan Sumberdaya Hutan Pada Masyarakat Kasepuhan, Banten Kidul. Bogor: Balitbang Kehutanan. Jurnal Penelitian Sosial dan Ekonomi Kehutanan Vol. 5 N. 4 Desember 2008, hal. $317-335$.

[12]. Sanders, D., and D. Cahill. 1999. Where incentives fit in soil conservation programs. In Incentives in Soil Conservation: From Theory to Practice, ed. D.W. Sanders, P.C. Huszar, S. Sombatpanit, and T. Enters, 11-24. Enfield, NH: World Association of Soil and Water Conservation, Science Publis

[13]. Soemantri, Gumilar Rusliwa, 2005. Penelitian Kualitatif. Jurnal Makara, Sosial Humaniora, Vol 9. No 2. Desember 2005 : pp 57-65

[14]. Thomas L. Saaty. 2008. Decision Making With The Analytic Hierarchy Process. Int. J. Services Sciences, Vol. 1, No. 1. 